\title{
REVISIT INTENTION TO HOSPITAL: FACTORS UNVEILED FROM A CASE STUDY OF BALIMED HOSPITAL
}

\author{
Harimukti Wandebori, \& IGN Ag. Ananda P. Pidada \\ School of Business Management, Institut Teknologi Bandung \\ E-mail: harimukti@sbm-itb.ac.id
}

\begin{abstract}
This study aims to investigate the effect of Service Quality Dimensions on Customer Satisfaction, the effect of Customer Satisfaction towards Patient Revisit Intention and searching a significant relationship between variables within the biggest private hospital in Denpasar Bali, RS BaliMed. Improving Service Quality and establishing Customer Satisfaction within the hospital will increase the Patient Revisit Intention, our motive is to find out the truth regarding the statement for RS BaliMed. This study adopted several literatures for the Service Quality, Customer Satisfaction and Revisit Intention assessment. In this study, 100 respondents' data were analyzed using PLS model and finds that Assurance and Empathy from Service Quality Dimensions have positive and significant influence toward Customer Satisfaction and also followed by the findings of Customer Satisfaction has positive and significant influence toward Revisit Intention. Interestingly this study also found that Reliability, Assurance and Empathy have indirect significant influence toward Revisit Intention which considered as unique findings.
\end{abstract}

Keyword: Hospital Service, Service Quality, Customer Satisfaction, Revisit Intention, Bali, Partial Least Square 


\section{Harimukti Wandebori \\ IGN Ag. Ananda P. Pidada}

\section{INTRODUCTION}

The needs of medical service among society in Denpasar-Bali drive the competition among health service provider. The tight competition among health service provider especially hospitals force the managements to create the most effective strategies in order to survive and become the leading hospital among others (Pramitari, 2013). In terms of this condition, quality is an essential indicator that affects the competitive advantage and an indicator to determine the demand of goods and services within a firm (Fitzsimmons \& Fitzsimmons, 1994). In line with this, the increasing number of hospitals in Bali from government and private parties resulted in intense competition among hospitals. Patients would choose to be loyal to a certain hospital that they considered have met their desires and needs, they will also revisit the hospital for future treatment when they are satisfied.

This paper will specifically discuss about BaliMed Hospital. BaliMed is the biggest private hospital with the highest number of doctors available in Bali. BaliMed established on January $8^{\text {th }}$ 2008, is located on Mahendradatta street No. 57 Denpasar, Bali. BaliMed Hospital hold their vision to be a trusted family oriented hospital that provides the best, most efficient, professional, rational and safest medical service. As the competition in health industry becomes more intense, BaliMed Hospital must be able to identify the impacts of service quality dimensions towards patient satisfaction and the effect of patient satisfaction on patient's revisit intention. The right strategy will make BaliMed Hospital able to retain its existence as the best private hospital in Bali.

Main outcome of this paper is to know the factors that influence customer satisfaction and lead patient's intention to revisit hospital by conducting SERVQUAL method in BaliMed Hospital.

\section{LITERATURE REVIEW}

\section{Service Quality and Its Dimensions}

Service quality is known as the overall evaluation on the excellence of services; it is the customer perception towards a service, and also the customer's judgment or their attitude related to the service. Moreover, Pasuraman, Berry and Zeithaml (1988) define service quality as a gap between expectations and perception of service quality and develop five dimensions of Service Quality (SERVQUAL). SERVQUAL divided in to five dimensions: (1) Tangibles (Physical facilities, equipment, and appearance of personnel); (2) Reliability (Ability to perform the promised service dependably and accurately); (3) Responsiveness (Willingness to help customer and provide prompt service); (4) Assurance (Knowledge and courtesy of employees and their ability to inspire trust and confidence); (5) Empathy (Caring, individualized attention the firm provides its customers).

Tangibles would include attributes representing the physical items such as equipment, buildings, and the appearance of both personnel and the devices utilized to communicate to the consumer. Bitner (1992) conducted her conceptual framework for examining the impact of physical surroundings as it related to both customers and employees. Moreover, study from Berry \& Parasuraman (1992) provided validation of the physical appearance on the consumer's assessment of quality. With the research by Bitner (1992), it was noted that 
physical appearance might influence the consumer's level of satisfaction considering appropriate service equipment could ease the medical treatment process.

Reliability relates to the personnel's ability to deliver the service in a dependable and accurate manner. Previous researchers, including Garvin (1987) found that reliability tends to always show up in the evaluation of service and indicated that reliability normally is the most important attribute consumers seek in the area of quality service. It was also determined by Parasuraman et al. (1991) that the conversion of negative wording to positive wording increased the accuracy of this dimension. Moreover, negative wording in the request for a customer response caused the customer to misinterpret this particular determinant. Walker (1995) found that if there is an adequate delivery of the basic level of service, then peripheral performance leads consumers to encounter satisfaction.

Responsiveness defined as the personnel's desire and willingness to assist customers and deliver a prompt service. Parasuraman et al. (1991) stated elements in responsiveness as telling the customer the exact time frame within which services will be performed, promptness of service, willingness of assistance, always available and never too busy to respond to customer requests. Bahia and Nantel (2000) disregarded responsiveness in their research, claiming a lack of reliability even though they recognized SERVQUAL and all of its dimensions as the best known, most universally accepted scale to measure perceived service quality.

Assurance defined as employees' knowledge and courteous that inspires confidence and trust from their customers which later established sense of assurance. In studies by Anderson et al. (1976), it was determined that a concrete level of trust in the organization and its treatment abilities was necessary to make the consumer comfortable enough to generate satisfaction and establish a relationship. Parasuraman et al. (1991) stated that actions by employees such as always giving courteous behavior with confidence and knowledge as prime elements of assurance.

Empathy is the caring and personalized attention the organization provides to its customers. Employees' individual attention and service convenient operating hours were the two primary elements in the evaluation of empathy (Parasuraman et al. 1991). The degree to which the customer feels the empathy will cause the customer to either accept or reject the service encounter, in the case of healthcare industry; patient satisfaction has also found a linkage between service quality and satisfaction. For example Anbori et al. (2010) shows that empathy dimension had strong influence on patient's willingness to come back to the hospital after being satisfied.

H1 : Tangible has significant influence towards Customer Satisfaction

H2 : Reliability has significant influence towards Customer Satisfaction

H3 : Responsiveness has significant influence towards Customer Satisfaction

H4 : Assurance has significant influence towards Customer Satisfaction

H5 : Empathy has significant influence towards Customer Satisfaction 


\section{Harimukti Wandebori \\ IGN Ag. Ananda P. Pidada}

\section{Customer Satisfaction}

Customer satisfaction is recognized in the marketing literature as an important and essential goal of all business activities (Wang and Lo, 2002). Customer satisfaction can be defined as the psychological state summary that achieved when customer's emotion expectations are conquered by the customer's prior feelings about their consumption and customer satisfaction also considered as an important factor of repurchase intention experience (Oliver and Linda, 1981). Besides of having an importance for its effect on repurchase intention, customer satisfaction is also labeled as the cheapest promotion tool (Pizam and Ellis, 1999). In the healthcare industry, past research on patient satisfaction has also found a linkage between service quality and satisfaction. For example, Anbori et al. (2010) shows that empathy and assurance dimensions had strong influence on patient's willingness to revisit the hospital after being satisfied. The related literature acknowledges the importance of repurchase and thus uses these two dimensions of Assurance and Empathy as consequences of service quality perceptions. The customer satisfaction is also found as the direct predictor of repurchase (Cronin and Taylor, 1992).

\section{Revisit intention}

Customer repurchase intention in a hospital can be considered as revisit intention, it is defined as a personal aim of the customer on sustaining the relationship with a service provider and purchasing the next service from the same one (Jones and Taylor, 2007). Revisit intention is triggered when customer had excellence and memorable service experience from previous visit which made them to satisfied (Bowen and Chen, 2001). Service provider has to make sure their customer have intention to revisit because when it comes to cost analysis, the amount of cost spent on attracting new customers is certainly higher than maintaining or engaging existing customers (Fornell, 1992).

\section{Bali Healthcare Industry}

The number of hospital in Bali is keep on rising constantly. Based on the Badan Pusat Statistik (BPS) data, the number of hospital available is increasing up to $8 \%$ from 2012 to 2014 . It is recorded the number of general hospital in 2014 is 49 units, 10 units are owned by the government and 39 units are owned by private. Furthermore the number of specialized hospital available is 5 units. Meanwhile, the number of hospital available specifically in Denpasar at the moment is 19 units. Among those hospitals, 2 general hospitals are owned by the government, 14 general hospitals are owned by private and the other 3 units are specialized hospitals. Hospital provider and management have to be able to anticipate the amount of population in a certain area therefore this condition also occurs in Bali. As recorded in Badan Pusat Statistik (BPS), Bali has the area of $5,636.66 \mathrm{~km}^{2}$ with the population of $4,152,800$. However, specifically, Denpasar has an area of $127.78 \mathrm{~km}^{2}$ with the population of 846,200 in $2013,863,600$ in 2014 and 880,600 in 2015 . It has $4.06 \%$ of growth rate from 2013 to 2015 (Badan Pusat Statistik, 2015).

\section{Proposed Model}

This study focuses on the effect of Service Quality on Customer Satisfaction and Revisit Intention in RS BaliMed. The following conceptual framework and hypothesis was based on literature review, provide the scope and depth of the study. 


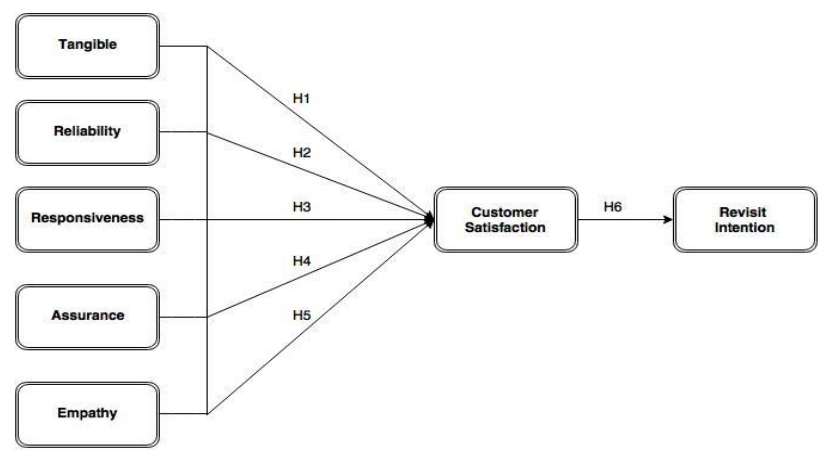

Figure 1 Conceptual Model

\section{METHODOLOGY}

\section{Questionnaire Distribution and Method}

Questionnaire was used to collect the data from respondents. The questionnaire consisted of two sections. The first section of the questionnaire was a socio-demographic to find respondent's background profile (respondent's name, gender, age, occupation, monthly income, number of treatment and reason of choosing the hospital). The second section includes questions to measure the dimensions of service quality, customer satisfaction and revisit intention. These questions were based on the literature of each variable. In section two, respondents were required to fill the data with 5-point Likert Scale as 1 for "Strongly Disagree" up to 5 for "Strongly Agree". All the data were collected from RS BaliMed's patients. The questionnaire was first pilot tested by 30 patients in RS BaliMed. After successfully pilot tested, the questionnaire was later distributed to 100 patients. The sampling number was implemented by Slovin formula calculation with 0.1 margin of error. Moreover, based on observation the questionnaire were spread on the most operating service in the hospital which includes Polyclinics, ER and several inpatients treatment. Whole 100 usable questionnaires were collected, $80 \%$ outpatients and $20 \%$ inpatients respondents. To ensure the high response rate, face to face interviews were conducted during the questionnaire distribution process. The questionnaire was in Bahasa Indonesia. SPSS 22 was used for the pilot test and SmartPLS 3 was used for the data analysis.

\section{Analysis of Model and Findings}

From total 100 respondents data collected, the background information is as below,

Table 1 Respondent's Backgorund Profile

\begin{tabular}{lcc}
\hline & Gender & \\
\hline Male & & $46 \%$ \\
& Age & $54 \%$ \\
$17-21$ & & $11 \%$ \\
$22-26$ & & $9 \%$ \\
$27-30$ & Occupation & $28 \%$ \\
$>30$ & Con & $52 \%$ \\
\hline
\end{tabular}


Harimukti Wandebori

IGN Ag. Ananda P. Pidada

\begin{tabular}{|c|c|}
\hline Student/College Students & $14 \%$ \\
\hline Government Employees & $7 \%$ \\
\hline Private Employees & $53 \%$ \\
\hline Other & $26 \%$ \\
\hline \multicolumn{2}{|c|}{ Monthly Salary } \\
\hline <Rp. 2.000.000 & $19 \%$ \\
\hline Rp. $2.000 .000-$ Rp. 5.000 .000 & $46 \%$ \\
\hline Rp. 5.000.000-Rp. 8.000 .000 & $31 \%$ \\
\hline >Rp. 8.000 .000 & $4 \%$ \\
\hline \multicolumn{2}{|c|}{ Number of Treatment } \\
\hline Once & $30 \%$ \\
\hline More than once & $70 \%$ \\
\hline \multicolumn{2}{|c|}{ Reason On Choosing the Hospital } \\
\hline Located Nearby & $36 \%$ \\
\hline Doctor Referral & $53 \%$ \\
\hline Other factor & $11 \%$ \\
\hline
\end{tabular}

The pilot test showed that every indicator within the variables is Valid and Reliable. Which indicated the questionnaire was suitable to be assessed further. The detail is shown on Table 2

Table 2 Pilot Test Result

\begin{tabular}{|c|c|c|c|c|c|c|c|}
\hline \multirow[t]{2}{*}{ Variable } & \multirow[t]{2}{*}{ Indicator } & \multirow{2}{*}{$\begin{array}{l}\text { Pearson } \\
\text { Correlation }\end{array}$} & \multirow{2}{*}{$\begin{array}{l}\text { Critical } \\
\text { Point }\end{array}$} & \multirow[t]{2}{*}{ Validity } & \multirow{2}{*}{$\begin{array}{l}\text { Cronbach's } \\
\text { Alpha }\end{array}$} & \multirow{2}{*}{$\begin{array}{l}\text { General } \\
\text { Standard }\end{array}$} & \multirow[t]{2}{*}{ Reliability } \\
\hline & & & & & & & \\
\hline \multirow[t]{3}{*}{ Tangible } & $\mathrm{Tl}$ & 0.710 & 0.300 & Valid & \multirow[t]{3}{*}{0.844} & \multirow[t]{3}{*}{0.600} & Reliable \\
\hline & $\mathrm{T} 2$ & 0.748 & 0.300 & Valid & & & Reliable \\
\hline & T3 & 0.674 & 0.300 & Valid & & & Reliable \\
\hline \multirow[t]{5}{*}{ Reliability } & RLI & 0.792 & 0.300 & Valid & \multirow[t]{5}{*}{0.921} & \multirow[t]{5}{*}{0.600} & Reliable \\
\hline & RL2 & 0.832 & 0.300 & Valid & & & Reliable \\
\hline & RL3 & 0.859 & 0.300 & Valid & & & Reliable \\
\hline & RL4 & 0.784 & 0.300 & Valid & & & Reliable \\
\hline & RL5 & 0.712 & 0.300 & Valid & & & Reliable \\
\hline \multirow[t]{4}{*}{ Responsiveness } & RS1 & 0.840 & 0.300 & Valid & \multirow[t]{4}{*}{0.904} & \multirow[t]{4}{*}{0.600} & Reliable \\
\hline & RS2 & 0.838 & 0.300 & Valid & & & Reliable \\
\hline & RS3 & 0.813 & 0.300 & Valid & & & Reliable \\
\hline & RS4 & 0.653 & 0.300 & Valid & & & Reliable \\
\hline \multirow[t]{4}{*}{ Assurance } & $\mathrm{Al}$ & 0.859 & 0.300 & Valid & \multirow[t]{4}{*}{0.921} & \multirow[t]{4}{*}{0.600} & Reliable \\
\hline & $\mathrm{A} 2$ & 0.856 & 0.300 & Valid & & & Reliable \\
\hline & A3 & 0.851 & 0.300 & Valid & & & Reliable \\
\hline & A4 & 0.719 & 0.300 & Valid & & & Reliable \\
\hline \multirow[t]{4}{*}{ Empathy } & El & 0.758 & 0.300 & Valid & \multirow[t]{4}{*}{0.889} & \multirow[t]{4}{*}{0.600} & Reliable \\
\hline & E2 & 0.802 & 0.300 & Valid & & & Reliable \\
\hline & E3 & 0.703 & 0.300 & Valid & & & Reliable \\
\hline & E4 & 0.761 & 0.300 & Valid & & & Reliable \\
\hline Customer & CS1 & 0.787 & 0.300 & Valid & 0.903 & 0.600 & Reliable \\
\hline
\end{tabular}


Tahun 10. No. 3, Desember 2017

\begin{tabular}{|c|c|c|c|c|c|c|c|}
\hline \multirow[t]{2}{*}{ Satisfaction } & CS2 & 0.774 & 0.300 & Valid & & & Reliable \\
\hline & CS3 & 0.866 & 0.300 & Valid & & & Reliable \\
\hline \multirow[t]{2}{*}{ Revisit Intention } & RII & 0.809 & 0.300 & Valid & \multirow[t]{2}{*}{0.894} & \multirow[t]{2}{*}{0.600} & Reliable \\
\hline & $\mathrm{RI} 2$ & 0.809 & 0.300 & Valid & & & Reliable \\
\hline
\end{tabular}

The Pearson Correlation of every indicator exceeded 0.3 which indicated them as Valid; moreover every variable's Cronbach's Alpha exceeded 0.6 which indicated them as Reliable.

After being pilot-tested the data should also be tested for its model Validity and Reliabilty, the result showed as below.

Table 3 Model Validity and Reliability Result

\begin{tabular}{|c|c|c|c|c|c|}
\hline \multirow[t]{2}{*}{ Variable } & \multirow[t]{2}{*}{ Indicator } & Factor & \multirow[t]{2}{*}{ (AVE) } & \multirow{2}{*}{$\begin{array}{l}\text { Cronbach's } \\
\text { Alpha }\end{array}$} & \multirow{2}{*}{$\begin{array}{l}\text { Composite } \\
\text { Reliability }\end{array}$} \\
\hline & & Loadings & & & \\
\hline \multirow[t]{3}{*}{ Tangible } & $\mathrm{Tl}$ & 0.835 & \multirow[t]{3}{*}{0.763} & \multirow[t]{3}{*}{0.820} & \multirow[t]{3}{*}{0.893} \\
\hline & T2 & 0.889 & & & \\
\hline & T3 & 0.849 & & & \\
\hline \multirow[t]{5}{*}{ Reliability } & RL1 & 0.821 & \multirow[t]{5}{*}{0.642} & \multirow[t]{5}{*}{0.861} & \multirow[t]{5}{*}{0.899} \\
\hline & RL2 & 0.828 & & & \\
\hline & RL3 & 0.813 & & & \\
\hline & RL4 & 0.812 & & & \\
\hline & RL5 & 0.727 & & & \\
\hline \multirow[t]{4}{*}{ Responsiveness } & RSI & 0.849 & \multirow[t]{4}{*}{0.710} & \multirow[t]{4}{*}{0.864} & \multirow[t]{4}{*}{0.907} \\
\hline & RS2 & 0.875 & & & \\
\hline & RS3 & 0.855 & & & \\
\hline & RS4 & 0.789 & & & \\
\hline \multirow[t]{4}{*}{ Assurance } & Al & 0.847 & \multirow[t]{4}{*}{0.677} & \multirow[t]{4}{*}{0.839} & \multirow[t]{4}{*}{0.893} \\
\hline & $\mathrm{A} 2$ & 0.880 & & & \\
\hline & A3 & 0.788 & & & \\
\hline & A4 & 0.770 & & & \\
\hline \multirow[t]{4}{*}{ Empathy } & El & 0.822 & \multirow[t]{4}{*}{0.666} & \multirow[t]{4}{*}{0.833} & \multirow[t]{4}{*}{0.888} \\
\hline & E2 & 0.832 & & & \\
\hline & E3 & 0.840 & & & \\
\hline & E4 & 0.768 & & & \\
\hline Customer & CSI & 0.837 & \multirow[t]{3}{*}{0.753} & \multirow[t]{3}{*}{0.836} & \multirow[t]{3}{*}{0.901} \\
\hline \multirow[t]{2}{*}{ Satisfaction } & CS2 & 0.877 & & & \\
\hline & CS3 & 0.888 & & & \\
\hline \multirow[t]{2}{*}{ Revisit Intention } & RII & 0.973 & \multirow[t]{2}{*}{0.770} & \multirow[t]{2}{*}{0.752} & \multirow[t]{2}{*}{0.868} \\
\hline & $\mathrm{R} / 2$ & 0.769 & & & \\
\hline
\end{tabular}

Factor Loadings, AVE, Cronbach's Alpha and Composite Reliability were used to evaluate the measurement model. Every Indicator's Factor Loading must exceed 0.7 in order to be considered Valid; AVE of every variable must exceed 0.5 for the further criterion of Validity. 


\section{Harimukti Wandebori}

IGN Ag. Ananda P. Pidada

Moreover in order to established reliability, Cronbach's Alpha and Composite Reliability must exceed 0.7. Overall the table above shows that every Variable is valid and reliable.

Furthermore, the research has collected statistical data to examine hypothesis and the effect size among variables.

\section{Table 4 Partial Effect}

\begin{tabular}{lllll}
\hline Hypothesis & Variable Correlation & $\begin{array}{l}\text { Parameter } \\
\text { Coefficient }\end{array}$ & T-Statistics & P-Values \\
\hline H1 & $\begin{array}{l}\text { Tangible->Customer } \\
\text { Satisfaction }\end{array}$ & 0.010 & 0.123 & 0.902 \\
\hline H2 & $\begin{array}{l}\text { Reliability->Customer } \\
\text { Satisfaction }\end{array}$ & 0.197 & 1.923 & 0.055 \\
\hline H3 & $\begin{array}{l}\text { Responsiveness-> } \\
\text { Customer Satisfaction }\end{array}$ & 0.110 & 1.113 & 0.266 \\
\hline H4 & $\begin{array}{l}\text { Assurance-> Customer } \\
\text { Satisfaction }\end{array}$ & 0.250 & 2.084 & 0.038 \\
\hline H5 & $\begin{array}{l}\text { Empathy-> Customer } \\
\text { Satisfaction }\end{array}$ & 0.402 & 4.179 & 0.000 \\
\hline Customer Satisfaction- & 0.670 & 9.640 & 0.000 \\
\hline
\end{tabular}

Table above shows the correlation among variables along with the effect size and its significant level. The hypothesis test is accepted at significant correlation among variables with T-Statistics above or equal to 1.96 and P-Values below or equal to 0.05 .

Tangible, Reliability and Responsiveness positively influence Customer Satisfaction with Parameter Coefficient of 0.010, 0.197 and 0.110 but not significantly. Meanwhile Assurance and Empathy positively influence Customer Satisfaction as much as 0.250 and 0.402 , the influence are also significant with both T-Statistics above 1.96 and P-Values below 0.05 . Customer Satisfaction is also influence Revisit Intention positively and significantly with Parameter Coefficient of 0.670 .

Overall the findings showed that three hypotheses were proven accepted and the other three are not. It also can be seen that in Service Quality Dimensions, Assurance and Empathy have significant influences toward Customer Satisfaction and Customer Satisfaction have significant influence towards Revisit Intention.

Table 5 Indirect Effect

\begin{tabular}{lrll}
\hline $\begin{array}{l}\text { Variable Correlation } \\
\text { (Mediated by Customer }\end{array}$ & Parameter Coefficient & T-Statistics & P-Values \\
$\begin{array}{l}\text { Satisfaction) } \\
\text { Tangible->Revisit Intention }\end{array}$ & 0.007 & & \\
Reliability-> Revisit & 0.132 & 0.123 & 0.902 \\
\hline
\end{tabular}




\begin{tabular}{|c|c|c|c|c|}
\hline Intention & & & & \\
\hline $\begin{array}{l}\text { Responsiveness-> } \\
\text { Intention }\end{array}$ & Revisit & 0.074 & 1.082 & 0.280 \\
\hline $\begin{array}{l}\text { Assurance-> } \\
\text { Intention }\end{array}$ & Revisit & 0.167 & 1.985 & 0.048 \\
\hline $\begin{array}{l}\text { Empathy-> } \\
\text { Intention }\end{array}$ & Revisit & 0.269 & 3.837 & 0.000 \\
\hline
\end{tabular}

The table above shows the additional information on the model, which is the Indirect Effect of Tangible, Reliability, Responsiveness, Assurance and Empathy toward Revisit Intention. It shows that the Effect were all positive, while the Variables that contribute significantly were Reliability, Assurance and Empathy because the Effect's T-Statistics are above 1.96 and the P-Values are below 0.05 .

The simultaneous effect among variables is shown as below.

Table 6 R-Square

\begin{tabular}{llll}
\hline Variable & R-Square & T-Statistics & P-Values \\
\hline Customer Satisfaction & 0.765 & 13.499 & 0.000 \\
Revisit Intention & 0.449 & 4.954 & 0.000 \\
\hline
\end{tabular}

It can be seen on the table above that Service Quality Dimensions as a whole influence as much as $76.5 \%$ toward Customer Satisfaction, while the other $23.5 \%$ of the effect was influenced from other factors which were not tested in the model.

Moreover Customer Satisfaction is also proven to influence Revisit Intention as much as $44.9 \%$, while the other $55.1 \%$ was influenced by other factors.

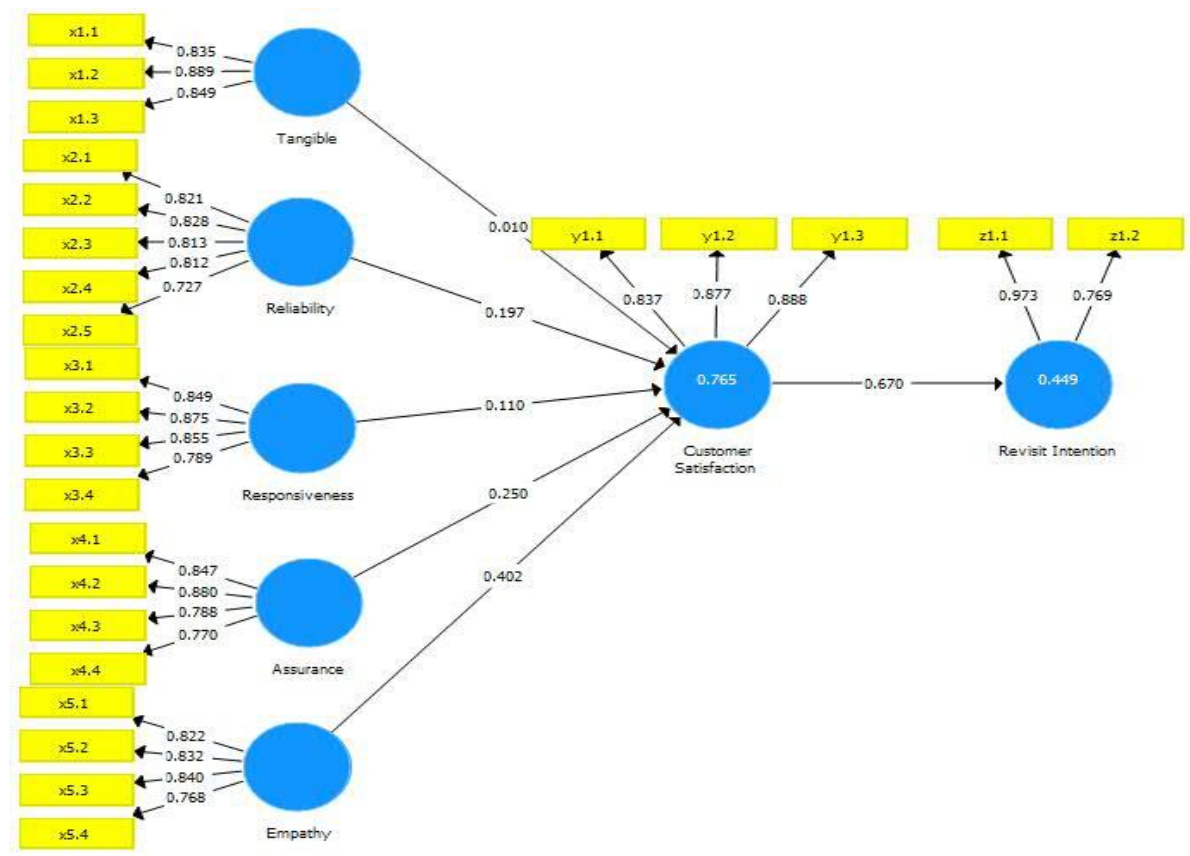

Figure 2 Partial Least Square Result 


\section{Harimukti Wandebori \\ IGN Ag. Ananda P. Pidada}

\section{CONCLUSION}

This study examines the impact of service quality dimensions on customer satisfaction and the impact of customer satisfaction on revisit intention in RS BaliMed, along with the patient's socio-demography aspect. Moreover, this study also examined the relationship among variables and proof statistical evidence for the significance.

The socio-demography data shows that the portion of female patients is slightly greater than the male patients. The majority of the respondents were above 30 years old, most of them working as private employees and the data also shows that respondent's monthly income were ranged from Rp. 2.000.000 to Rp. 5.000.000. Moreover, the majority of the respondents have visited RS BaliMed more than once and the main reason on choosing RS BaliMed is doctor recommendation.

After the research has been conducted, it shows that Assurance and Empathy have significant and positive influence toward Customer Satisfaction, this indicates that most of the patients in RS BaliMed were satisfied by the employees' knowledge that embrace patient's confident which leads them to establish assurance towards the treatment, patients also satisfied after getting personal care and attention from the hospital. It goes in line with literature study by Anbori et al. (2010). On the other hand three others Service Quality Dimensions which are Tangible, Reliability and Responsiveness are proven to have positive influence toward Customer Satisfaction but the effects are not yet significant.

Moreover, the result shows that Customer Satisfaction also have significant and positive influence towards Revisit Intention, it indicates that patients in RS BaliMed triggered to revisit for further treatment when they had excellence and memorable service experience from previous visit which they considered satisfying. It goes in line with the literature of Oliver (1981).

There is synergy between the findings in this study with the study by Kitapci et al. (2014) which studied about the hospital service quality in Turkey. Both study found that Assurance and Empathy have significant influence toward Customer Satisfaction; moreover, Customer Satisfaction also has significant influence towards Patient Revisit Intention. Additionally, this study found some new and interesting findings, the statistical evidence showed that indirectly some of the Service Quality Dimensions are influencing Revisit Intention significantly. The study showed that Reliability, Assurance and Empathy have significant influence toward Revisit Intention which were mediated by Customer Satisfaction, this indicates that patient tend to revisit RS BaliMed for further treatment after they experienced appropriate treatment, established assurance and getting personal care from the employees.

Overall, the findings are important for RS BaliMed to evaluate their performance and maintaining their quality. RS BaliMed must do some effort on modernize the current situation. Several limitations are related to the research design and the sample. Further research could improve the number of sample to maximize the research validity and also studying others factors that influence revisit within the hospital. Further research should also be done in any other Hospital in Bali to compare findings and collecting new data. 


\section{References}

Anbori, A. K., Ghani, S. N., Yadav, H., \& Su, T. T. (2010). Patient Satisfaction and Loyalty to The Private Hospitals in Sana'a, Yemen. International Journal for Quality in Health Care, 310-315.

Anderson, W. T., Cox, E. P., \& Fulcher, D. G. (1976). Bank Selection Decisions and Market Segmentation. Journal of Marketing .

Babakus, E., \& Mangold, W. G. (1992). Adapting the SERVQUAL Scale to Hospital Services: An Empirical Investigation. Haelth Service Research , 767-786.

Badan Pusat Statistik, B. (2015). Retrieved 2015, from http://bali.bps.go.id/: http://bali.bps.go.id/Subjek/view/id/30\#subjekViewTab3 | accordion-daftar-subjek1

Berry, L. L., \& Parasuraman, A. (1992). Marketing Services: Competing Through Quality. Journam of Marketing, 132-134.

Bitner, M. J. (1992). Servicescapes: The Impact of Physical Surroundings On Customers and Employees. Journal of Marketing, 57-71.

Bowen, J. T., \& Chen, S.-L. (2001). The Relationship Between Customer Loyalty and Customer Satisfaction. International Journal of Contemporary Hospitality Management , 213-217.

Caruana, A. (2002). Service Loyalty: The Effects of Service Quality and The Mediating Role of Customer Satisfaction. European Journal of Marketing , 811-828.

Cronin, J. J., \& Taylor, S. A. (1992). Measuring Service Quality: A Re-Examination and Extension. Journal of Marketing Vol.56, 55-68.

Effendy, N. (1998). Dasar-Dasar Keperawatan Kesehatan Masyarakat Edisi 2. Jakarta: Penerbit Buku Kedokteran EGC.

Fitzsimmons, J. A., \& Fitzsimmons, M. J. (1994). Service Management for Competitive Advantage. Mcgraw-Hill College.

Fornell, C. (1992). A National Customer Satisfaction Barometer: The Swedish Experience. Journal of Marketing, 6-21.

Garvin, D. A. (1987). Competing on the Eight Dimensions of Quality. Harvard Business Review .

Hair Jr., J. F., Hult, G. T., \& Ringle, C. M. (2013). A Primer on Partial Least Squares Structural Equation Modeling (PLS-SEM). SAGE.

Isik, O., Tengilimoglu, D., \& Akbolat, M. (2011). Measuring Health Care Quality with the SERVQUAL Method: A Comparison in Public and Private Hospitals. Healthmed, 19211930.

Jones, T., \& Taylor, S. F. (2007). The Conceptual Domain of Service Loyalty: How Many Dimensions. Jornal of Service Marketing , 36-51.

Kandampully, J., \& Suhartanto, D. (2000). CustomerLloyalty in The Hotel Industry: The Role of Customer Satisfaction and Image. International Journal of Contemporary Hospitality Management, 346-351.

Kang , B.-S., Cho , C.-H., \& Baek, J.-D. (2007). The Effects of Service Quality on Customer Satisfaction in Case of. Asian Journal on Quality , 27-39.

Kitapci, O., Akdogan, C., \& Dortyol, I. T. (2014). The Impact of Service Quality Dimensions on Patient Satisfaction, Repurchase Intentions and Word-of-Mouth Communication in the Public Healthcare Industry . Procedia - Social and Behavioral Sciences, 161-169.

Oliver, R. L. (1997). Satisfaction: A Behavioral Perspective on the Consumer. McGraw Hill.

Oliver, R. L., \& Linda, G. (1981). Effect of Satisfaction and Its Antecedents on Consumer Preference and Intention. Advances in Consumer Research Volume $08,88-93$.

Parasuraman, A., Berry, L. L., \& Zeithaml, V. A. (1988). SERVQUAL: A Multiple-Item Scale for Measuring Consumer Perceptions of Service Quality. Journal of Retailing , 12-43.

Parasuraman, A., Zaithaml, V. A., \& Berry, L. L. (1991). Refinement and Reassessment of The SERVQUAL Scale. Journal of Retailing, 420-50.

Pizam, A., \& Ellis, T. (1999). Customer Satisfaction and Its Measurement in Hospitality Enterprises. International Journal of Contemporary Hospitality Management , 326-339.

Pramitari, I. G. (2013). Usulan Penerapan Sistem Activity Based Costing Pada Instalasi Radiologi Rumah Sakit Balimed. Jakarta: Universitas Indonesia. 


\section{Harimukti Wandebori}

\section{IGN Ag. Ananda P. Pidada}

Saragih, R., Lubis, A. N., \& Sutatniningsih, R. (2010). Pengaruh Mutu Pelayanan Kesehatan Terhadap Loyalitas Pasien Rumah Sakit Umum Herna, Medan. Program Studi S2 IImU Kesehatan Masyarakat Fakultas Kesehatan Masyarakat Universitas Sumatera Utara .

Walker, J. L. (1995). Service Encounter Satisfaction: Conceptualized. Journal of Services Marketing , 5-14.

Wang, Y., \& Lo, H.-P. (2002). Service Quality, Customer Satisfaction and Behavior Intentions: Evidence from China's Telecommunication Industry. Info , 50-60.

Woodside, A. G., Frey, L., \& Daly, R. T. (1990). Linking Service Quality, Customer Satisfaction, and Behavioral Intention. Journal of health care marketing , 5-17. 